\title{
Contribution of Mathematical Anxiety, Learning Motivation and Self-Confidence to Student's Mathematical Problem Solving
}

\author{
Irhamna $^{1}$, Zul Amry ${ }^{2}$, Hermawan Syahputra ${ }^{3}$ \\ ${ }^{1}$ Postgraduate Program in Mathematics Education Department, Universitas Negeri Medan, Indonesia \\ ${ }^{2,3}$ Universitas Negeri Medan, Indonesia \\ iamna94@yahoo.com
}

\begin{abstract}
The objectives of this study are to: (1) Analyze whether there is a contribution of mathematics anxiety, learning motivation and selfconfidence to the ability to solve mathematical problems simultaneously, (2) Analyze whether there is a contribution of mathematics anxiety, learning motivation and self-confidence to the partial mathematical problem solving ability, (3) To analyze how big the contribution of mathematics anxiety, learning motivation and self-confidence to mathematical problem solving abilities simultaneously, (4) Analyze how much the contribution of mathematics anxiety, learning motivation and self-confidence to the partial mathematical problem solving abilit, (2) math anxiety questionnaire, (3) learning motivation questionnaire, (4) selfconfidence questionnaire. Data analysis was performed by multiple linear regression analysis. The results showed: (1) There is a contribution to mathematics anxiety, learning motivation, and selfconfidence to the ability to solve mathematical problems simultaneously, (2)There is a contribution to mathematics anxiety, learning motivation, and self-confidence to the ability to solve mathematical problems partially, (3) Mathematical anxiety, learning motivation and self-confidence contributed $26 \%$ to the ability to solve mathematical problems simultaneously, (4) Mathematical anxiety contributed $8.5 \%$ to mathematical problem solving abilities, learning motivation contributed $15.8 \%$ to mathematical problem solving abilities and self-confidence contributed $16.7 \%$ to mathematical problem solving abilities.
\end{abstract}

Keywords

mathematical anxiety; learning motivation; self confidence; mathematical problem solving ability

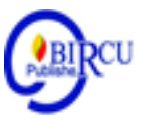

\section{Introduction}

Mathematics is a universal science. Mathematics is also seen as the queen of science. Ruseffendi (2010) said that "mathematics is not only a tool for mathematics itself, but many concepts that are indispensable for other sciences, such as chemistry, physics, biology, engineering and pharmacy". Sakirudeen \& Sanni (2017) also said that "Mathematics is the cradle of all creations, without which the world cannot move an inch. $\mathrm{Be}$ it a cook or a farmer, a carpenter or a mechanic, a shopkeeper or a doctor, an engineer or a scientist, a musician or a magician, everyone needs mathematics in their day-to-day lift"e. This shows that mathematics has become a part of our daily lives.

Given the important role of mathematics in everyday life, mathematics learning should be given more attention. Learning in schools continues to develop in accordance with the times where the hope of learning mathematics can optimally develop students' 
talents and abilities (Maulydia, 2017). However, the high demand to master mathematics is inversely proportional to student achievement. Pranoto (Saragih, 2018) stated that the victories of Indonesian students in various international Olympic events did not seem to improve the quality of Indonesian students. On the contrary, around 76.6 percent of junior high school level students were judged to be mathematics blind. And then Baswedan (Saragih, 2018) said that counting from a scale of 6, the math abilities of Indonesian students were only at the second level. Ironically, this condition has persisted since 2003, meaning that for a dozen years the condition has not changed. For this reason, these facts force students and teachers to work hard in improving the quality of mathematics. One of the important targets in achieving this learning achievement is to maximize learning in problem-solving abilities.

\section{Review of Literatures}

According to Sugiharto (2020) education is one of the efforts to improve the ability of human intelligence, thus he is able to improve the quality of his life. Education is the most important thing for the development of a nation's civilization. In setting up a stable education system, of course, it takes a long and tiring process to achieve high quality standards (Junifran, 2020). The learning achievement in prose appreciation material is that students are able to enjoy, enjoy, react, and produce old prose and new prose such as: fairy tales, legends, short stories and novels. Local wisdom can be used as a motivator for students to learn to value and appreciate literature through the process of learning prose appreciation material. Prose consists of short stories, novels and other fictional stories with local wisdom as the basis and all of this is poured into an independent teaching material in the form of modulesMathematical problem solving skills are a major part of the learning objectives to be achieved in mathematics (Surya et al, 2017) because problem solving plays an important role in mathematics education from elementary to secondary level students. However, the fact is that students' mathematical problem solving abilities are still far from the expectations of educators. In the PISA survey in 2015, Indonesia ranked 63 out of 72 participating countries with an average math score of 386 with an average international score of 490. The factor that causes the low achievement of Indonesian students in PISA is the weak ability to solve non-routine or high-level problems. he questions tested in PISA consist of 6 levels (lowest level 1 to level 6 (highest)). Meanwhile, students in Indonesia are only familiar with routine questions at level 1 and 2 (Inayah, 2018). In addition to the results of the PISA assessment, one proof that students' mathematical problem-solving abilities are low is the result of observations by researchers through a preliminary study conducted on 96 grade VIII students of junior high school in Kualasimpang City Sub-district on social arithmetic material. Overall, the explanation of the results of the observations is as follows: in understanding the problem, there are 13\% of students who are able to understand the problem while $74 \%$ of students still cannot understand the problem presented. In making solving plans and doing calculations, $10 \%$ of students answered by making the correct completion and calculation procedures and $22 \%$ of students answered by making the completion procedure by guessing without using concepts from social arithmetic that had been previously taught by the math teacher even though In calculating the results obtained, the answer is correct, while 52\% of students answered with wrong procedures and calculations. Only $12 \%$ of students made the conclusions contained in the problem solving problem. And $12 \%$ of other students did not answer the questions given by the observer. Based on this case, the researcher concluded 
that the problem that occurred in all junior high schools in Kualasimpang City Sub-district was that students were still unable to solve the problems give.

The low ability of students to solve mathematical problems is influenced by several factors, both external and internal factors (Wahyuddin, 2016). Recently, a lot of research only focuses on external factors such as learning methods or strategies, when in fact, when viewed in fact, internal factors have a fairly large role in the ability to solve mathematical problems (Sukarti, 2018). This is due to the mathematical problems themselves, which are not routine and require a level of understanding that is not simple. So that it can cause conflict in students.

Sieber (Rosmawati, 2017), said that the conclusion can be one of the inhibiting factors in learning that can interfere with the performance of a person's function if the level is felt to be heavy, such as in concentration, remembering, concepts and problems. Mathematical anxiety has become a global problem that should have caught the world's attention ((Luttenberger, Wimmer \& Peachter, 2018). Fennema and Sherman (Disai, Dariyo \& Basaria, 2017) said Mathematical Anxiety is a feeling that involves fear when faced with the possibility of dealing with math problems. Mathematics anxiety adversely affects the implementation and outcomes of mathematics learning. According to the results of research by Olaniyan and Medinat (Rawa \& Yasa, 2018), students who are indicated by mathematics anxiety will argue that mathematics is difficult to learn, students do not like mathematics, refuse to do math assignments, and even skip class during math class hours. This is because math anxiety causes students to find it difficult to learn and apply mathematical concepts (Gleason, 2008). His also agrees Cockroft (Rawa \& Yasa, 2018) who stated that students grow up without liking mathematics at all. They consider mathematics to be a subject that is not fun, difficult to understand with various tasks or problems that are difficult, and not everyone can do it. This will have an impact on students' mathematics learning achievement.

In the learning process, motivation is needed (Kompri, 2016). Motivation to learn plays an important role in providing passion or enthusiasm for learning, so that students who are strongly motivated have a lot of energy to carry out learning activities (Winkel, 2009). Sardiman (2012) states that learning outcomes will be optimal, if there is motivation. This means that there is good motivation in learning, it will produce good learning outcomes as well. The intensity of student learning motivation will greatly determine the level of achievement of student learning outcomes. According to Mc Donald Motivation (Kompri, 2016) is a change in energy in a person's personality which is marked by the emergence of affective (feelings) and reactions to achieve goals, so that the emergence of motivation in individuals can be realized or not. Motivation to learn is a nonintellectual psychological factor (Sardiman, 2011). Strong motivation in students will increase interest, willingness and high enthusiasm for learning, because motivation and enthusiasm for learning have a close relationship. This concurs with Begle, E.G. (Trisnawati et al, 2015) which states that more than half of the studies linking motivation to learning achievement. Meanwhile, Jemudin, Makur \& Ali's (2019) research shows that learning motivation has a close relationship with learning achievement. The higher the value of learning motivation, the higher the learning achievement. According to Elliot (Trisnawati et al, 2015), people who have greater motivation will achieve higher result. However, from the research results of Rotgans \& Henk (2012), which states that motivation is not directly related to one of the measures of academic outcomes (behavior related to academic achievement). From this opinion it can be seen the importance of examining how the influence of motivation on student achievement, especially in students' mathematical problem solving abilities. 
Self-confidence is one important factor that affects the academic achievement of students (Amir \& Risnawati, 2016). This agrees with Yates (Hendriana, Rohaeti \& Sumarmo, 2017) who stated that self-confidence is very important for students to be successful in learning mathematics. With self-considence, students will be more motivated and prefer to learn mathematics so that in the end it is hoped that the achievement of learning mathematics will also be more optimal. With self-confidence, students have the ability to take appropriate and effective actions in various situations, even when challenges arise from themselves or from others (Burton, 2006). Self-confidence in students is also useful for creating learning atmosphere that supports students in carrying out learning activities as well as possible, being honest in doing assignments and believing in the results of their own hard work without having to cheat with others (Sophia \& Wutsqa, 2015). Often students are not able to show their abilities optimally because they feel unsure that they are able to complete the tasks assigned to them.

In connection with the above problems as well as the problems that the researchers found in learning mathematics at juior high school in Kualasimpang City Sb-district after conducting preliminary written interviews with 96 students including: 1). 88\% Students feel anxious when faced with mathematics, and try to avoid mathematics; 2). $90 \%$ of students are not motivated in learning mathematics; 3). $87 \%$ of students are not brave enough to respond to teachers. 4). $84 \%$ of students respond to failure negatively. Looking at the problems above, it is necessary to do research with the title: "Contribution of Mathematical Anxiety, Learning Motivation and Self-Confidence Against Mathematical Problem Solving Ability"

\section{Research Method}

In this study, the design used is descriptive design and the analysis of the relationship between variables (causal model) is used to measure the relationship between research variables or to analyze how the influence of a variable on other variables. And then the data were collected ex-post fact with a sample of 235 students who were in all junior high schools in Kualasimpang City Sub-district. The population of this study were all students of class IX in Kualasimpang City Sub-District, consisting of 2 State Junior High Schools and 2 State Private Junior High Schools, totaling 570 students. The sample in this study was taken by using area random sampling technique.

This research involves independent variables and dependent variables. The independent variables in this study were mathematics anxiety, learning motivation and self-confidence. The dependent variable is the ability to solve mathematical problems. The instruments used in this study consisted of a mathematical problem solving ability test instrument containing 5 essay items, a mathematics anxiety questionnaire containing 30 statements, a learning motivation questionnaire containing 30 statements and a selfconfidence questionnaire containing 33 statement items.

Quantitative data were obtained through tests of mathematical problem solving abilities, mathematics anxiety questionnaires, learning motivation questionnaires and selfconfidence questionnaires. Data processing begins with testing the statistical requirements needed as a basis for hypothesis testing. Furthermore, multiple linear regression analysis was carried out to test the first, second and third and fourth hypotheses while pathway descriptive analysis was carried out to test the fifth hypothesis. Data processing was carried out with the help of the SPSS version 21.0. 


\section{Discussion}

The data described in this study included the test data of students' mathematical problem solving abilities (Y), mathematical maturity (X1), learning motivation (X2) and self-confidence (X3) which were taken from 235 junior high school students in Kualasimpang city sub-district. The results of the calculations can be seen in table 1:

Table 1. Summary of the Results of the Value of Research Variables

\begin{tabular}{|l|l|l|l|l|}
\hline STATISTIK & $\mathrm{Y}$ & $\mathrm{X}_{1}$ & $\mathrm{X}_{2}$ & $\mathrm{X}_{3}$ \\
\hline Min & 40 & 40 & 37,50 & 41,36 \\
\hline Max & 92,31 & 79,17 & 92,50 & 69,24 \\
\hline Mean & 63,75 & 61,18 & 67,60 & 53,62 \\
\hline Std. Deviation & 12,02 & 6,23 & 12,29 & 5,59 \\
\hline
\end{tabular}

\subsection{Hypothesis 1}

The multiple regression models will be tested with the following hypothesis:

$$
\begin{aligned}
& H_{0}: \beta_{1}=\beta_{2}=\beta_{3}=0 \\
& H_{a}: \exists \beta_{i} \neq 0, \forall i, i=1,2,3
\end{aligned}
$$

The testing criteria when viewed from the F price are as follows:

- $F_{\text {Calculate }}<F_{\text {table }}$, then accept $\mathrm{H}_{0}$ means that the regression model is meaningless and not linear

- $F_{\text {Calculate }}>F_{\text {table }}$, then reject $\mathrm{H} 0$ means that the regression model is meaningful and linear

Table 2. ANOVA Test Results for Simultaneous Contribution ANOVA $^{\mathrm{a}}$

\begin{tabular}{|cc|c|c|c|c|c|}
\hline \multicolumn{2}{|c|}{ Model } & Sum of Squares & df & Mean Square & F & Sig. \\
\hline \multirow{4}{*}{1} & Regression & 8809,441 & 3 & 2936,480 & 27,111 &, $000^{\mathrm{b}}$ \\
& Residual & 25020,526 & 231 & 108,314 & & \\
& Total & 33829,967 & 234 & & & \\
\hline
\end{tabular}

a. Dependent Variable: Pemecahan Masalah (Y)

b. Predictors: (Constant), Kepercayaan Diri (X3), Kecemasan Matematika(X1), Motivasi Belajar(X2) 


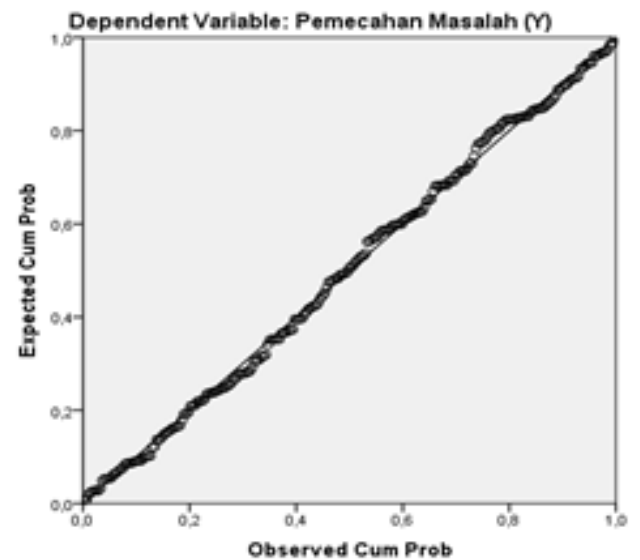

Figure 1. Simultaneous Multiple Regression Linearity Test Graph

In the ANOVA table it can be seen that the regression $\mathrm{F}_{\text {count }}$ value is 27,111 while based on the $F_{\text {table }}$ it is obtained $F_{\text {table }}=2.64$, this shows that $F_{\text {count }}>F_{\text {table }}$ and the significance is 0.000 (less than 0.05 ) then reject $\mathrm{H}_{0}$, which means that the regression model is meaningful and linear. This is also reinforced by the linearity graph in Figure 1 which states that the regression model is linear. So it can be concluded that math anxiety $\left(\mathrm{X}_{1}\right)$, learning motivation $\left(\mathrm{X}_{2}\right)$ and self-confidence $\left(\mathrm{X}_{3}\right)$ contribute to mathematical problem solving abilities (Y) simultaneously. Andri, Zagir and Dores (2017) said in their research that psychological factors contributed a percentage of variance of $10.097 \%$. Student psychological factors, namely factors that contribute to each student's psyche, if their soul is disturbed, their learning outcomes will also be disturbed. The psychological factors in question consist of attention, interest, self-confidence and motive or motivation. Furthermore, the results of research conducted by Octavia (2015) say that the relationship between affective and cognitive abilities is $70 \%$. So it can be seen that the cognitive domain has a close relationship with the affective domain.

\subsection{Hypothesis 2}

a. Mathematical anxiety contributes to mathematical problem solving abilities.

The linear regression equation formed from the variable problem-solving ability (Y) on mathematics anxiety $\left(\mathrm{X}_{1}\right)$ is $\hat{Y}=36,293-0,332 X_{1}$.

Table 3. ANOVA Test Results for Mathematical Anxiety Contributes to Mathematical Problem Solving Ability

ANOVA $^{\mathrm{a}}$

\begin{tabular}{|cc|c|c|c|c|c|}
\hline & Model & $\begin{array}{c}\text { Sum of } \\
\text { Squares }\end{array}$ & df & Mean Square & F & Sig. \\
\hline \multirow{3}{*}{1} & Regression & 2881,105 & 1 & 2881,105 & 21,691 &, $000^{\mathrm{b}}$ \\
& Residual & 30948,862 & 233 & 132,828 & & \\
& Total & 33829,967 & 234 & & & \\
\hline
\end{tabular}




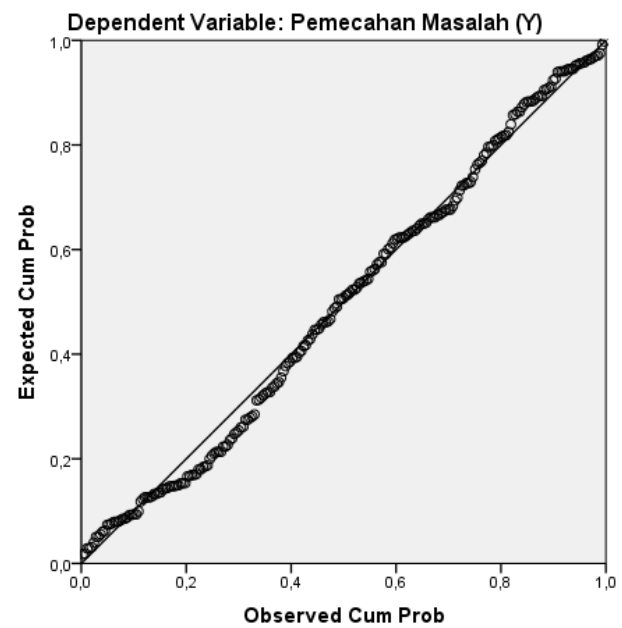

Figure 2. Multiple Regression Linearity Test Graph

In the ANOVA table it can be seen that the value of the regression Fcount is 21.691 while based on table $F$ it is obtained $F_{\text {table }}=3.88$, this shows that $F_{\text {count }}>F_{\text {table }}$ and a significance of 0.000 (less than 0.05) then reject $\mathrm{H} 0$ which means the regression model is meaningful and linear. This is also reinforced by the linearity graph in Figure 2 which states that the regression model is linear. So it can be concluded that mathematics anxiety $\left(\mathrm{X}_{1}\right)$ contributes to mathematical problem solving abilities (Y). Hidayat \& Rahmatudin (2018) said that there is a negative and significant relationship between mathematics anxiety and students' academic abilities. This means that mathematics anxiety can be used to predict the level of student academic ability. As well as mathematics anxiety has a $35 \%$ contribution to the academic ability of students. Noor (2017) said in his research that there was a relationship between student anxiety and students' ability to solve math problems. Furthermore, Lesti, Fitriza and A (2020) said in their research that there was a closeness of the negative contribution of math anxiety to the ability to solve math problems with a contribution value of $86.3 \%$. And Aunurrofiq \& Junaed (2017) said that mathematical anxiety has a significant contribution and has a negative relationship to problem solving abilities. if high mathematical anxiety results in low students' mathematical problem solving abilities, and vice versa if their mathematical anxiety is reduced resulting in high student mathematical problem solving abilities As well as Qausarina (2016) concluded that there was a significant positive correlation between math anxiety and the mathematics learning outcomes of class X IPA students at SMA Negeri 11 Banda Aceh, which was 0.24 which was in the low category.

b. Motivation to learn contributes to mathematical problem solving abilities.

The linear regression equation formed from the problem solving ability variable (Y) on learning motivation $\left(\mathrm{X}_{2}\right)$ is $\hat{Y}=36,293+0,245 X_{2}$. 
Tabel 4. ANOVA Test Results for Learning Motivation Contribute to Mathematical Problem Solving Ability

ANOVA $^{\mathrm{a}}$

\begin{tabular}{|c|r|r|r|r|r|}
\hline Model & Sum of Squares & df & Mean Square & F & Sig. \\
\hline Regression & 5348,369 & 1 & 5348,369 & 43,754 &, $000^{\mathrm{b}}$ \\
1 Residual & 28481,598 & 233 & 122,239 & & \\
Total & 33829,967 & 234 & & & \\
\hline
\end{tabular}

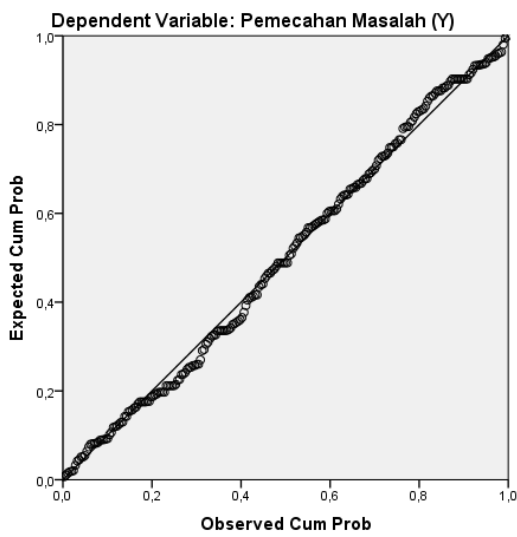

Figure 3. Multiple Regression Linearity Test Graph

In the ANOVA table it can be seen that the price of the regression $F_{\text {count }}$ is 43,754 while based on the $F$ table it is obtained $F_{\text {table }}=3.88$, this shows that $F_{\text {count }}>F_{\text {table }}$ and the significance is 0.000 (less than 0.05 ) then reject $\mathrm{H} 0$ which means the regression model is meaningful and linear. This is also reinforced by the linearity graph in Figure 3 which states that the regression model is linear. So it can be concluded that learning motivation $\left(\mathrm{X}_{2}\right)$ contributes to mathematical problem solving abilities $(\mathrm{Y})$.

This finding agrees with Wuladari, Azhar and Jusra (2018) in their research that learning motivation contributes to students' mathematical problem solving abilities. That is, if the motivation to learn is high, then the problem solving ability is also high, so that learning motivation is one of the supporting factors that cannot be ignored in the achievement of students' mathematical problem solving abilities. Sappaile and Pristiwaluyo (2019) state that the contribution of motivation and self-concept to solving math problems is $71 \%$ of students of the Mathematics Study Program of the Faculty of Mathematics and Natural Sciences, Makassar State University. Rigusti and Pujiastuti (2020) said in their research that students who have high problem solving abilities will have high motivation too, for students who have moderate problem solving abilities will have moderate motivation and students who have low problem solving abilities will have low motivation too. As well as Koshkouei et al (2016) in their research concluded that self-concept, motivation to learn mathematics and self-regulation have a significant contribution to mathematics learning achievement. However, self-concept has a large contribution to students' mathematics learning achievement. Wahyudin (2016) stated in his research that metacognition, learning motivation, creativity in learning had a significant positive contribution to students' problem solving abilities so that it could be interpreted 
that the better metacognition, learning motivation and learning creativity had, the problemsolving abilities for these students the higher it is.

c. Self-confidence contributes to mathematical problem solving abilities

The linear regression equation formed from the variable problem-solving ability (Y) on self-confidence $(\mathrm{X} 3)$ is $\hat{Y}=36,293+0,245 X_{3}$.

Table 5. ANOVA Test Results for Confidence Contributes to Mathematical Problem Solving Ability

ANOVA $^{\mathrm{a}}$

\begin{tabular}{|cc|c|c|c|c|c|}
\hline \multicolumn{2}{|c|}{ Model } & Sum of Squares & $\mathrm{df}$ & Mean Square & $\mathrm{F}$ & Sig. \\
\hline \multirow{3}{*}{1} & Regression & 5656,744 & 1 & 5656,744 & 46,783 &, $000^{\mathrm{b}}$ \\
& Residual & 28173,223 & 233 & 120,915 & & \\
& Total & 33829,967 & 234 & & & \\
\hline
\end{tabular}

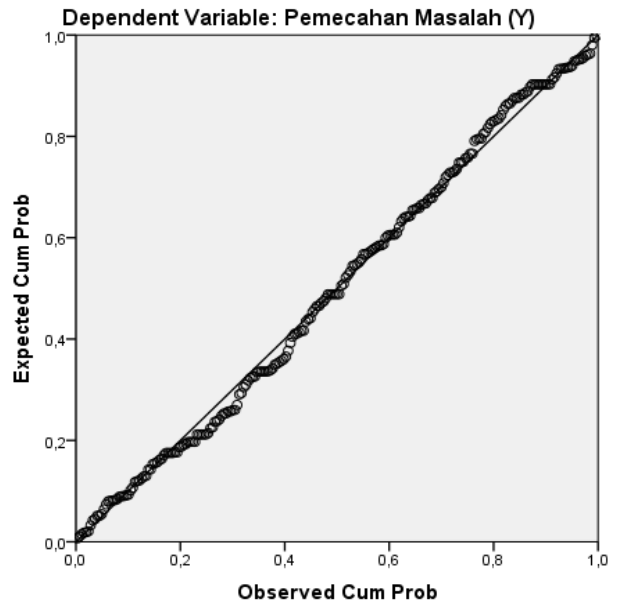

Figure 4. Multiple Regression Linearity Test Graph

In the ANOVA table it can be seen that the value of the regression $F_{\text {count }}$ is 46.783 while based on table $F$ it is obtained Ftable $=3.88$, this shows that $F_{\text {count }}>F_{\text {table }}$ and the significance is 0.000 (less than 0.05) then reject $\mathrm{H} 0$ which means the regression model is meaningful and linear. This is also reinforced by the linearity graph in Figure 4 which shows that the regression model is linear. So it can be concluded that self-confidence $\left(\mathrm{X}_{3}\right)$ contributes to mathematical problem solving abilities (Y). The results of this study agree with several studies that have been conducted. Dewi and Minarti (2018) concluded in their research that students 'self-confidence in mathematics learning had a positive effect on students' mathematical problem solving abilities. And Wulandari and Sinambela's research (2017) in their research says that there is a relationship between self-confidence and students' mathematical problem solving abilities using the PBL model in Kisaran. As well as Harjuna, Tiro and Alimuddin (2016) stated that self-confidence has a positive effect on mathematics learning achievement, both directly and indirectly (through independent learning). Lutfiyah, Rukmigarsari and Fathani (2019) concluded that there was a significant effect of self-confidence on students' mathematical problem solving abilities which were positive. This means that the higher the student's self-confidence, the higher 
the ability to solve mathematical problems, the effect is $83 \%$. However, this is inversely proportional to the findings of Putra et al (2018) who concluded that students' selfconfidence in mathematics lessons was good. Even though the students' problem solving ability is still low, it does not weaken their confidence in finding solutions to problems. This proves that there is no relationship between self-confidence and mathematical problem solving abilities.

\subsection{Hypothesis 3}

The value of the determinant coefficient $\left(\mathrm{R}^{2}\right)$ reflects how much the contribution of the independent variable $\mathrm{X}$ to the dependent variable $\mathrm{Y}$ can be found simultaneously using SPSS 21.0 and the results can be seen in table 6 below:

Tabel 6. Simultaneous Determinant Coefficient Model Summary ${ }^{\mathrm{b}}$

\begin{tabular}{|c|c|c|c|c|c|c|c|c|c|}
\hline \multirow[b]{2}{*}{ Model 1} & \multirow[b]{2}{*}{$\mathrm{R}$} & \multirow[b]{2}{*}{$\begin{array}{c}\mathrm{R} \\
\text { Square }\end{array}$} & \multirow[b]{2}{*}{$\begin{array}{l}\text { Adjusted R } \\
\text { Square }\end{array}$} & \multirow[b]{2}{*}{$\begin{array}{c}\text { Std. Error of the } \\
\text { Estimate }\end{array}$} & \multicolumn{5}{|c|}{ Change Statistics } \\
\hline & & & & & $\begin{array}{c}\text { R Square } \\
\text { Change }\end{array}$ & F Change & df1 & $\mathrm{df} 2$ & $\begin{array}{l}\text { Sig.F } \\
\text { Change }\end{array}$ \\
\hline 1 &, $510^{\mathrm{a}}$ &, 260 &, 251 & 10,40740 & ,260 & 27,111 & 3 & 231 &, 000 \\
\hline
\end{tabular}

The determinant coefficient or $\mathrm{R}^{2}$ is 0.26 . This shows that math anxiety, learning motivation and self-confidence contribute $26 \%$ to problem solving abilities simultaneously. Meanwhile, $74 \%$ is determined by other variables.

\subsection{Hypothesis 4}

a. Determinant Coefficient between Mathematical Anxiety $\left(\mathrm{X}_{1}\right)$ on Mathematical Problem Solving Ability (Y)

Tabel 7. Determinant Coefficient between Mathematical Anxiety $\left(\mathrm{X}_{1}\right)$ Against Mathematical Problem Solving Ability (Y) Model Summary ${ }^{\mathrm{b}}$

\begin{tabular}{|c|c|c|c|c|c|c|c|c|c|}
\hline \multirow[t]{2}{*}{ Model } & \multirow[t]{2}{*}{$\mathrm{R}$} & \multirow{2}{*}{$\begin{array}{c}\mathrm{R} \\
\text { Square }\end{array}$} & \multirow{2}{*}{$\begin{array}{l}\text { Adjusted } \\
\text { R Square }\end{array}$} & \multirow{2}{*}{$\begin{array}{c}\text { Std. } \\
\text { Error of the } \\
\text { Estimate }\end{array}$} & \multicolumn{5}{|c|}{ Change Statistics } \\
\hline & & & & & $\begin{array}{c}\text { R Square } \\
\text { Change }\end{array}$ & $\begin{array}{c}\mathrm{F} \\
\text { Change }\end{array}$ & df1 & $\mathrm{df} 2$ & $\begin{array}{l}\text { Sig.F } \\
\text { Change }\end{array}$ \\
\hline 1 &, $292^{a}$ & ,085 & ,081 & 11,52509 & ,085 & 21,691 & 1 & 233 &, 000 \\
\hline
\end{tabular}

The determinant coefficient of $\mathrm{R}^{2}$ is 0.085 . This shows that math anxiety contributes $8.5 \%$ to mathematical problem solving.

b. Determinant Coefficient between Learning Motivation $\left(\mathrm{X}_{2}\right)$ and Mathematical Problem Solving Ability (Y) 
Tabel 8. Determinant Coefficient between Learning Motivations $\left(X_{2}\right)$ Against Mathematical Problem Solving Ability (Y)

Model Summary

\begin{tabular}{|c|c|c|c|c|c|c|c|c|c|}
\hline \multirow[t]{2}{*}{ Model } & \multirow[t]{2}{*}{$\mathrm{R}$} & \multirow{2}{*}{$\begin{array}{c}\mathrm{R} \\
\text { Square }\end{array}$} & \multirow{2}{*}{$\begin{array}{l}\text { Adjusted R } \\
\text { Square }\end{array}$} & \multirow{2}{*}{$\begin{array}{c}\text { Std. } \\
\text { Error of the } \\
\text { Estimate }\end{array}$} & \multicolumn{5}{|c|}{ Change Statistics } \\
\hline & & & & & $\begin{array}{c}\text { R Square } \\
\text { Change }\end{array}$ & $\begin{array}{c}\mathrm{F} \\
\text { Change }\end{array}$ & dfl & $\mathrm{df} 2$ & $\begin{array}{l}\text { Sig.F } \\
\text { Change }\end{array}$ \\
\hline 1 &, $398^{\mathrm{a}}$ & ,158 & , 154 & 11,05616 & ,158 & 43,754 & 1 & 233 & ,000 \\
\hline
\end{tabular}

The determinant coefficient or $\mathrm{R}^{2}$ is 0.158 . This shows that learning motivation contributes $15.8 \%$ to problem solving abilities.

c. Determinant Coefficient between Confidence $\left(\mathrm{X}_{3}\right)$ and Mathematical Problem Solving Ability (Y)Kemampuan Pemecahan Masalah Matematis (Y)

Tabel 9. Determinant Coefficient between Learning Motivation $\left(\mathrm{X}_{2}\right)$ Against Mathematical Problem Solving Ability (Y) Model Summary ${ }^{\mathrm{b}}$

\begin{tabular}{|c|c|c|c|c|c|c|c|c|c|}
\hline \multirow[t]{2}{*}{ Model } & \multirow[t]{2}{*}{$\mathrm{R}$} & \multirow[b]{2}{*}{$\begin{array}{c}\mathrm{R} \\
\text { Square }\end{array}$} & \multirow{2}{*}{$\begin{array}{c}\text { Adjusted R } \\
\text { Square }\end{array}$} & \multirow{2}{*}{$\begin{array}{c}\text { Std. Error } \\
\text { of the } \\
\text { Estimate }\end{array}$} & \multicolumn{5}{|c|}{ Change Statistics } \\
\hline & & & & & $\begin{array}{c}\text { R Square } \\
\text { Change }\end{array}$ & F Change & dfl & $\mathrm{df} 2$ & Change \\
\hline 1 & $409^{\mathrm{a}}$ & , 167 &, 164 & 10,99614 & , 167 & 46,783 & 1 & 233 & ,000 \\
\hline
\end{tabular}

The determinant coefficient or $\mathrm{R}^{2}$ is 0.167 . This shows that self-confidence contributes $16.7 \%$ to problem-solving abilities.

\section{Conclusion}

Based on the results of the analysis of research data on the contribution of math anxiety, learning motivation and self-confidence to mathematical problem solving abilities, the following conclusions are obtained:

1. There is a simultaneous contribution of mathematics anxiety, learning motivation, and self-confidence to the ability to solve mathematical problems at junior high school in Kualasimpang City Sub-district..

2. There is a partial contribution to mathematics anxiety, learning motivation, and selfconfidence on the ability to solve mathematical problems in junior high school in Kualasimpang City Sub-district.

3. The determinant coefficient or $\mathrm{R}^{2}$ is 0.26 . This shows that math anxiety, learning motivation and self-confidence contribute $26 \%$ to problem solving abilities simultaneously. Meanwhile, $74 \%$ is determined by other variables.

4. The coefficient of determination or $\mathrm{R}^{2}$ is 0.085 . This shows that math anxiety contributes $8.5 \%$ to problem solving abilities.

5. The determinant coefficient or $\mathrm{R}^{2}$ is 0.158 . This shows that learning motivation contributes $15.8 \%$ to problem solving abilities.

6. The determinant coefficient or $\mathrm{R}^{2}$ is 0.167 . This shows that self-confidence contributes $16.7 \%$ to problem-solving abilities. 


\section{References}

Amir. Z., \& Risnawati. (2016). Psikologi Pembelajaran Matematika. Yogjakarta: Aswaja Pressindo.

Andri, Zagir .Z., \& Dores. J.O. (2017). Analisis Faktor-Faktor Yang Mempengaruhi Rendahnya Prestasi Belajar Siswa Pada Mata Pelajaran Matematikadi SD Negeri 04 Bati Tahun Pelajaran 2016/2017. Jurnal Pendidikan Dasar PerKhasa. Volume 3 No.2

Andri, Zagir .Z., \& Dores. J.O. (2017). Analisis Faktor-Faktor Yang Mempengaruhi Rendahnya Prestasi Belajar Siswa Pada Mata Pelajaran Matematikadi SD Negeri 04 Bati Tahun Pelajaran 2016/2017. Jurnal Pendidikan Dasar PerKhasa. Volume 3 No.2

Aunurrofiq. M., \& Junaed. I. (2017). Kecemasan Matematik Siswa dalam Menyelesaikan Soal-Soal Pemecahan Masalah. Unnes Journal of Mathematics Education Research. Volume 6 No.2.

Burton, K. \& Platts, B. (2006). Building confidence for dummies. West Sussex: John Wiley \& Sons, Ltd

Dewi. V.S., \& Minarti. D.E. (2018). Hubungan antara self-Confidence Terhadap Matematika Dengan Kemampuan Pemecahan Masalah Siswa Pada Materi Lingkaran. Mosharafa: Jurnal Pendidikan Matematika. Volume 7 Nomor 2

Disai, I.W, Dariyo, A, \& Basaria, D. (2017). Hubungan Antara Kecemasan Matematika Dan Self-Efficacy Dengan Hasil Belajar Matematika Siswa SMA X Kota Palangka Raya . Jurnal Muara Ilmu Sosial, Humaniora, dan Seni. Vol. 1, No. 2.

Gleason. J. (2008). Relationships Between Pre-Service Elementary Teachers' Mathematics Anxiety And Content Knowledge For Teaching. Journal of Mathematical Sciences \& Mathematics Education. Volume 3(1)

Hendriana, H., Rohaeti.E. E., \& Sumarmo. U. (2017). Hard Skills dan Soft Skills Matematik Siswa. Bandung: Refika Aditama

Hidayat. R., \& Rahmatudin. J. (2018). Kontribusi Mathematics Anxiety Terhadap Kemampuan Akademik Mahasiswa Pada Pembelajaran Kalkulus. Phenomenon. Vol. 08(No. 2).

Inayah. S. 2018. Penerapan Pembelajaran Kuantum Untuk Meningkatkan Kemampuan Pemecahan Masalah Dan Representasi Multipel Matematis Siswa. KALAMATIKA Jurnal Pendidikan Matematik. Volume 3, No. 1

Jemudin. E.D.F., Makur, P.A. \& Ali. A.F,. (2019). Hubungan Sikap Belajar dan Motivasi Belajar terhadap Prestasi Belajar Matematika Siswa SMPN 6 Langke Rembong. Journal of Honai Math. Vol. 2, No. 1, pp. 1-11

Jemudin. E.D.F., Makur. P.A., \& Ali. A.F. (2019). Hubungan Sikap Belajar dan Motivasi Belajar Terhadap Prestasi Belajar Matematika Siswa SMPN 6 Langke Rembong. Journal Of Honai Math. Volume 2 No. 1

Junifran, Rosliani. (2020). The Development of Sociocultural Malay-Based on Folklore Teaching Materials for Class X at SMA N 1 Percut Sei Tuan Deli Serdang. Budapest International Research and Critics in Linguistics and Education (BirLE) Journal Vol 3 (4): 1670-1685.

Kompri. (2016). Motivasi Pembelajaran Perspektif Guru dan Siswa. Bandung: PT Remaja Rosdakarya Offset 
Lesti. H., Fitriza. R., \& A. H. (2020). Pengaruh Kecemasan Matematika (Mathematics Anxiety) Terhadap Kemampuan Pemecahan Masalah Peserta Didik Kelas VII MTs. Math Educa Journal. Volume 4(1).

Lutfiyah. L., Rukmigarsari. E., \& Fathani H.A. (2019). Pengaruh Kecemasan Matematika Dan Kepercayaan Diri Terhadap Kemampuan Pemecahan Masalah Matematis Siswa Pada Materi Aritmetika Sosial SMP Negeri 14 Malang. JP3. Volume 14 No. 6

Maulydia, S.S. (2017). Hubungan Antara Kemampuan Representasi Matematis Dengan Kepercayaan Diri, Kemandirian Belajar, Motivasi Belajar, Disposisi Matematis Dan Gender Siswa SMK. Tesis

Noor. F. (2017). Kecemasan Dan Kemampuan Siswa Dalam Memecahkan Masalah Matematika. Math Didactic: Jurnal Pendidikan Matematika. Vol. 3 No. 3

Nurhayati. (2011). Pengaruh Sikap Dan Kebiasaan Tehadap Hasil Belajar Matematika. Jurnal Formatif. Volume 3 No.1. 247-254

Octavia. F. (2015). Analisis Kemampuan Siswa Kelas X Pada Ranah Kognitif, Afektif dan Psikomotorik. OMEGA Jurnal Fisika Dan Pendidikan Fisika. Volume 1 No. 2.

Putra. D.H., Putri. S.A.W., Fitriana. U., \& Andayani. F. (2018). Kemampuan Pemecahan Masalah Matematis dan Self-Confidence Siswa SMP. SJME. Vol.2 No.1.

Rawa. R.S. \& Yasa. M.E.A.P. (2018). Kecemasan Pada Mahasiswa Pendidikan Guru Sekolah Dasar. Journal Of Education Technology. Vol 2(2) pp. 36 -45.

Rigusti. W., \& Pujiastuti. H. (2020). Analisis Kemampuan Pemecahan Masalah Ditinjau dari Motivasi Belajar Matematika Siswa. Prima: Jurnal Pendidikan Matematika. Vol. 4 No. 1.

Rosmawati. 2017. Penerapan Layanan Konseling Untuk Mengatasi Kecemasan Siswa. JURKAM. Volume 1 No.1

Rotgans \& Henk. (2012). The Intricate Relationship between Motivation and Achievement: Examining the Mediating Role of Self-Regulated Learning and Achievement-Related Classroom Behaviors. International Journal of Teaching and Learning in Higher Education. Volume 24 Number 2.

Russeffendi, E.T. (2010). Dasar-Dasar Penelitian Pendidikan dan Bidang Non-Eksakta Lainnya. Bandung: Tarsito.

Sakirudeen, O.A. \& Sanni, B.K. (2017). Study Habits And Academic Performance Of Secondary School Students In Mathematic: A Case Study Of Selected Secondary Schools In Uyo Local Education Council. Research in Pedagogy. Vol. 7 (2). pp 283-297

Sappaile. I. B., \& Pristiwaluyo. T. (2019). The Effect Of Learning Motivation And SelfConcept On Mathematical Problems. DAYA MATEMATIS: Jurnal Inovasi Pendidikan Matematika. Volume7 No.1

Saragih, I.S. (2018). Perbedaan Kemampuan Pemecahan Masalah Matematis Dan Motivasi Belajar Siswa Smp Budi Agung Medan Yang Diajar Melalui Model Pembelajaran Kooperatif Dengan Model Pembelajaran Kontekstual Berbantuan Software Geogebra. Tesis. Program Pascasarjana Unimed.

Sardiman. A .(2012). Interaksi danMotivasi Belajar Mengajar. Jakarta: PT Raja Grafindo Persada

Sophia, F. H., \& Wutsqa. U.D,. (2015). Keefektifan Pendekatan Realistik Ditinjau dari Prestasi Belajar, Kemampuan Pemecahan Masalah, dan Kepercayaan Diri Matematika. Pythagoras. Volume 10 Nomor 2.

Sugiharto. (2020). Geographical students' learning outcomes on basic political science by using cooperative learning model with Group Investigation (GI) type in State University of Medan, Indonesia, Journal of Human Behavior in the Social 
Environment, 30:4, 447-456, DOI: 10.1080/10911359.2019.1696261.Sukarti. H. (2018). Hubungan Kecemasan Dan Kemampuan Siswa Dalam Menyelesaikan Masalah Matematika. Jurnal Pendidikan Informatika Dan Sains.Vol.7 No.1.

Surya, E. Putri, F.A. \& Mukhtar. (2017). Improving Mathematical Problem-Solving Ability and Self-Confidence of High School Students through Contextual Learning Model. Journal on Mathematics Education, 8(1), 85-94.

Syahputra, E. (2013). Peningkatan Kemampuan Spasial Siswa Melalui Penerapan Pembelajaran Matematika Realistik. Cakrawala Pendidikan November 2013 Th.XXXII No.3 : Yogyakarta

Trisnawati, dkk. (2015). Perbandingan Keefektifan Quantum Teaching dan TGT pada Pembelajaran Matematika Ditinjau dari Prestasi dan Motivasi. Jurnal Riset Pendidikan Matematika. Volume 2 Nomor 2 (297-307).

Wahyudin. (2016). Pengaruh Metakognisi, Motivasi Belajar, Dan Kreativitas Belajar Terhadap Kemampuan Pemecahan Masalah Siswa Kelas VIII SMP Negeri 2 Sabbangparu Kabupaten Wajo. Jurnal Daya Matematis. Volume 4 No. 1.

Wahyudin. (2010). Monograf: Kecemasan Matematika. Bandung: Program Studi Pendidikan Matematika SPS UPI.

Winkel. W.S. (2009). Psikologi Pengajaran. Jakarta : Gramedia

Wuladari. E.A., Azhar. E., \& Jusra. H. (2018). Antara Motivasi Belajar Terhadap Kemampuan Pemecahan Masalah Matematis Siswa Pada Kelas VII. Seminar Nasional Pendidikan Matematika 2018. Vol. 01. E-ISSN: 2477-4812

Wulandari \& Sinambela. NJM. (2017). Hubungan Kepercayaan Diri (Self-Confidence) dengan Kemampuan Pemecahan Masalah Matematika Siswa Dengan Menggunakan Model Problem Based Learning di MAN Kisaran. Jurnal Inspiratif. Volume 3 No.2 